\title{
Hormonal and behavioural changes during the mating season and pregnancy in Alpine marmots (Marmota marmota)
}

\author{
C. Exner ${ }^{1}$, A. Wehrend ${ }^{2}$, R. Hospes ${ }^{2}$, A. Einspanier ${ }^{3}$, \\ B. Hoffmann ${ }^{2}$ and G. Heldmaier ${ }^{1}$ \\ ${ }^{1}$ Department of Biology Animal Physiology, Philipps University of Marburg, Karl von Frisch Str. 8, 35043 \\ Marburg, Germany; ${ }^{2}$ Clinic for Obstetrics, Gynaecology and Andrology of Large and Small Animals, \\ Justus-Liebig-Universität Gießen, Frankfurter Strasse 106, 35392 Gießen, Germany; \\ and ${ }^{3}$ Institute of Physiology and Chemistry of the Veterinarian Faculty, University of Leipzig, \\ An den Tierkliniken 1, 04103 Leipzig, Germany
}

\begin{abstract}
Under natural and artificial conditions, Alpine marmots (Marmota marmota) are true hibernators with a single breeding season starting immediately upon emergence from hibernation. Over three mating and breeding seasons, hormonal and mating patterns of colony-housed reproductive female marmots were investigated after exit from hibernation. Blood samples were taken for progesterone, oestrogen and relaxin assays with parallel ultrasound investigations. Copulations were observed from the first day after exit from hibernation until the end of pregnancy and reached a maximum number on day 37 before parturition. Mating behaviour was observed between the dominant animals as well as between dominant and sub-
\end{abstract}

dominant group members. In the first week after exit from hibernation, plasma progesterone was detected in half of the animals. During the third week, progesterone concentrations were significantly higher in pregnant than in non-pregnant animals or animals that had aborted. Immediately after emerging from hibernation, all successfully mated females showed higher serum relaxin values than non-successfully mated animals and this increase in relaxin concentration lasted until the end of pregnancy. The total concentration of oestrogen did not differ between pregnant and non-pregnant animals. The results of this study indicate that progesterone and relaxin might be useful indicators of early pregnancy in Alpine marmots.

\section{Introduction}

The Alpine marmot (Marmota marmota) lives above the tree-line at altitudes of 900-3200 m in the Alps, Pyrenees and Carpathians (Krapp, 1978). The animals live in groups of up to 20 individuals, consisting of a dominant pair, subdominant adults, and yearlings. Towards the end of September, marmots cease all aboveground activity and retreat into their protected hibernacula, where they experience a continuous decrease of ambient temperature from $12^{\circ} \mathrm{C}$ in autumn to $0^{\circ} \mathrm{C}$ in spring. Typically, they hibernate in groups of 4-12 animals (Arnold et al., 1991). Hibernation is a wellregulated adaptive response to conditions of low ambient temperature and food shortages that occur in winter. During continued hibernation, metabolic rate is low and frequently interrupted by bursts of heat production (Ortmann and Heldmaier, 2000). Nevertheless, the energetic costs of hibernation are high for all group members, but in particular for females who gave birth

Email: exner@staff.uni-marburg.de to litters in the previous year (Heldmaier et al., 1993; Körtner and Heldmaier, 1995). The marmots emerge from hibernation before the thaw is over and when no food is available in the wild for several days or weeks. The very short mating season begins immediately after the end of hibernation (Psenner, 1957; Bibikow, 1996). Female reproductive success is determined by the physical fitness of the individual animal and social relations within the group (Arnold, 1990; Perrin et al., 1993a). The offspring of a social group stem from the dominant females, although subdominant females may also mate (Arnold, 1990; Hackländer and Arnold, 1999). The gestation period in Marmota marmota ranges from 34 (Psenner, 1957) to 37 days and is followed by 45 days of lactation. The average litter size is 2.4 pups (Blumstein and Armitage, 1998).

As wild marmots spend most of their lives in underground burrows, observations on reproductive biology during mating and the subsequent period of gestation are limited. Thus, in the present study social behaviour was recorded in addition to serum progesterone, oestrogen and relaxin concentrations in captive marmot family groups after emergence from hibernation, in order to gain 
further information on the endocrine functions in the narrow time window these animals have for reproduction. Ultrasonography was used to diagnose pregnancy and document fetal development.

\section{Materials and Methods}

\section{Animals and treatments}

A colony of Alpine marmots, kept at the University of Marburg in Germany, was observed during the mating season and the subsequent period of gestation (from the end of March until mid-May) for 3 years. The age of the animals ranged from 3 to 11 years. The eight females of the population lived in five social groups containing at least one sexually mature male (three groups (male, female): 1,$1 ; 2,1 ; 1,2$; two family groups: 2,2 and their juveniles). The social groups were caged separately during the study. The size of the enclosures ranged from 12 to $15 \mathrm{~m}^{2}$. Each pen included one litter box, several artificial tubes, tree trunks, and natural bedding material. Animals were fed ad libitum. The animal keeper trained the female marmots used in this study to become accustomed to handling. For the purpose of taking blood samples and performing ultrasonography, the animals were held by the back of the neck using two hands and automatically stiffened into an upright position.

Ultrasonography to detect and monitor pregnancy was carried out using a portable Siemens Sonoline Prima ultrasound unit with a real-time B-mode linear scanner $7.5 \mathrm{MHz}$ for transabdominal sonography. Ten parturitions (the pregnancy group) were investigated during the observation period. Three females became pregnant in the first and the last year of the study. Three females originally diagnosed as pregnant aborted or resorbed (the abortion group). The group of females in whom pregnancy was not detectable (11 observations) by ultrasonography served as a (non-pregnant) control group. For determination of serum progesterone, oestrogen and relaxin, blood samples were taken from the vena saphena of female animals twice a week. EDTA $(2 \% \mathrm{w} / \mathrm{v})$ was added to the samples and, after centrifugation for $10 \mathrm{~min}$ at $1500 \mathrm{~g}$, the plasma was stored at $-20^{\circ} \mathrm{C}$.

In additon to ultrasonography and blood sampling, body weight was measured and recorded once a week.

The mating and social behaviour of three groups of animals (one group with one male and one female; two groups with two males and two females) was observed during one mating season. The behaviour was monitored over a period of 3 months (from the end of March until the end of June) with at least $100 \mathrm{~h}$ of observation time for each group. Copulations, social interactions and the defence of territory were recorded. Social interactions were differentiated according to whether they involved clearly positive (smelling, grooming, playing or mating) or clearly negative behaviour (biting or fighting; Barash, 1976; Perrin et al., 1993b).

\section{Radioimmunoassays}

Progesterone. The standard operation procedure for the progesterone assay established in the present authors' laboratory refers to the method described by Hoffmann et al. (1973, 1992). Briefly, $0.1 \mathrm{ml}$ plasma is extracted with $2 \times 2 \mathrm{ml}$ hexane. The pooled extracts are then evaporated and submitted to radioimmunoassay. Dissolution and achievement of equilibrium is enhanced by a first incubation at $37^{\circ} \mathrm{C}$ for $20 \mathrm{~min}$, followed by an incubation for $60 \mathrm{~min}$ in a bath of melting ice. The assay is set up as an equilibrium assay using an antiserum directed against 4-pregnane-Il $\alpha$-ol-3,20-dione-HS-bovine serum albumin (BSA) (final dilution 1:50000). Separation of bound and free hormone is by charcoal absorption. On the basis of the use of bovine plasma samples as a positive control, the interassay coefficient of variation was $12.8 \%$. The detection limit is about $32 \mathrm{fmol}$ per tube. All values were corrected for the reagent blank.

Total oestrogens. Plasma $(0.1 \mathrm{ml})$ was extracted with $2 \times 2.5 \mathrm{ml}$ toluene. The pooled extracts were evaporated to dryness and submitted to radioimmunoassay. Redissolution of the extracted oestrogens was ensured by adding $0.08 \mathrm{ml} 0.1 \mathrm{~N} \mathrm{NaOH}$ with $0.1 \%$ BSA to the samples, which were then kept for $10 \mathrm{~min}$ at $37^{\circ} \mathrm{C}$. Addition of $0.01 \mathrm{ml} 0.08 \mathrm{~N} \mathrm{HCl}$ and $0.01 \mathrm{ml}$ 'concentrated' phosphate buffer $\left(2.686 \mathrm{~g} \mathrm{KH}_{2} \mathrm{PO}_{4}, 8.356 \mathrm{~g} \mathrm{Na}_{2} \mathrm{HPO}_{4}\right.$ and $0.325 \mathrm{~g} \mathrm{NaN}_{3}$ and $200 \mathrm{ml} \mathrm{H}_{2} \mathrm{O}$ ) ensured an adjustment to radioimmunoassay conditions. The assay was set up as a sequential assay to improve sensitivity (Strecker et al., 1979; Hoffmann et al., 1992). After the addition of $0.4 \mathrm{ml}$ antiserum (antiserum: Gi-E1-Ges; obtained after immunization of a rabbit with oestradiol-17HS-BSA; final dilution 1:120000, equal crossreaction with oestrone and oestradiol, none with non-phenolic steroids; Hoffmann, 1977 ) and $0.1 \mathrm{ml}$ standard buffer solution (oestrone: $3.69 \mathrm{fmol}$ to $0.945 \mathrm{pmol}$ per tube), a first 'overnight' incubation (minimum $12 \mathrm{~h}$ ) at $4^{\circ} \mathrm{C}$ was performed. $\left[{ }^{3} \mathrm{H}\right]$ oestrone $(96.81 \mathrm{fmol}=0.326 \mathrm{KBq}$ per tube) was then added and the samples were again incubated for $60 \mathrm{~min}$ at $4{ }^{\circ} \mathrm{C}$. Separation of free and bound hormone was by charcoal absorption. Mean recovery $(n=8)$ of 18.5 and $55.4 \mathrm{fmol}$ was determined from spiked bovine plasma samples at 99 and $105 \%$, respectively, and the interassay coefficient was $22.2 \%$. The detection limit was about $8 \mathrm{fmol}$ per tube. All values were corrected for the reagent blank.

Relaxin. During a period of 2 years, serum relaxin concentrations were measured in five pregnant females, five non-pregnant females and one female that had aborted. Serum relaxin concentration was determined using a relaxin enzyme immunoassay as described by Einspanier et al. (1999). Briefly, 96-well plates were coated with the secondary goat anti-rabbit IgG antibody (Santa Cruz Biotechnology Inc., Santa Cruz, CA) and 
incubated. Serum samples $(50 \mu \mathrm{l})$ were pipetted into the wells and incubated at room temperature in the dark with two different polyclonal rabbit anti-porcine relaxin antibodies (serum 258, courtesy of O. D. Sherwood, Department of Molecular and Integrative Physiology, University of Illinois, or R6, courtesy of B. Steinetz, Nelson Institute of Environmental Medicine, New York University School of Medicine) at a final dilution of 1: 800000 . After $6 \mathrm{~h}$, the biotinylated relaxin tracer (porcine relaxin, courtesy of O. D. Sherwood) was added for $21 \mathrm{~h}$ at $4^{\circ} \mathrm{C}$, and then horseradish peroxidasecoupled streptavidin solution was added for $30 \mathrm{~min}$ at $4^{\circ} \mathrm{C}$ in the dark. After several washings, the colour was developed with the substrate solution $(90 \mathrm{mmol}$ sodium acetate $\mathrm{I}^{-1}, 4.5 \mathrm{mmol}$ citric acid $\mathrm{I}^{-1}, 0.004 \%$ $(\mathrm{v} / \mathrm{v}) \mathrm{H}_{2} \mathrm{O}_{2}, 0.01 \%(\mathrm{w} / \mathrm{v})$ tetramethylbenzidine in $2 \%$ $(\mathrm{w} / \mathrm{v})$ dimethylsulphoxide). The reaction was stopped after 40 min incubation by application of $50 \mu \mathrm{l} 0.2 \mathrm{~mol}$ $\mathrm{H}_{2} \mathrm{SO}_{4} \mathrm{I}^{-1}$, and the yellow product was measured at $450 \mathrm{~nm}$ in a spectrophometer. Human recombinant $\mathrm{H} 2$ relaxin (courtesy of J. Tregear, Howard Florey Institute, University of Melbourne) as well as porcine relaxin (courtesy of O. D. Sherwood) was used to generate a standard curve. The lower limit of quantification was $0.1 \mu \mathrm{g}$ per serum sample. The crossreactivities of the assay for insulin, transforming growth factor and insulinlike growth factor were $<1 \%$. All serum samples were measured with both polyclonal anti-porcine antiserum and showed similar results. Interassay variation was $15.3 \%$ and intra-assay variation was an average of $11.2 \%$. The accuracy of the assay was further assessed by determining serial relaxin concentrations in the sera of two marmots, the pregnancies of which were confirmed by ultrasonography. Their parallelism was also confirmed by ultrasonography.

\section{Statistical analyses}

All data are expressed as mean \pm SEM. For comparisons between two groups, Student's $t$ test for paired or unpaired samples was used when data showed a normal distribution. Comparisons among more than two groups were performed using a one-way ANOVA. When the conditions for using a parametric procedure were not fulfilled, the groups were compared using a Kruskal-Wallis test followed by multiple comparisons when necessary. Statistical evaluation of the data was performed with the help of SPSS 10.0.

The experiments were performed in accordance with German animal welfare legislation (Deutsches Tierschutzgesetz 25. Mai 1998 (BGBL I S.1105)).

\section{Results}

The body weight of female marmots after awaking from hibernation ranged from 1740 to $3210 \mathrm{~g}$, and the initial mean weight of marmots that became pregnant was slightly higher $(2699 \pm 87 \mathrm{~g} ; n=10)$ than that of those that did not $(2356 \pm 44 \mathrm{~g} ; n=11 ; P=0.052)$. Compared with non-pregnant females, body weight gain in pregnant females was not significantly different $(58.3 \pm 10.1 \mathrm{~g}$ per week $(n=7)$ versus $63.2 \pm 7.4 \mathrm{~g}$ per week $(n=7) P>0.05)$. Thus, until parturition, the mean body weight of pregnant females remained higher than that of non-pregnant females (3076 $\pm 160 \mathrm{~g}$; $n=7$ versus $2504 \pm 109 \mathrm{~g} ; n=7 ; P<0.05$ ). Weight gain was calculated from the first day after emergence from hibernation to one day before parturtion. Only healthy and uninjured females were investigated.

In the first week after emergence from hibernation, when mating activity was high, plasma progesterone concentrations were not detectable (limit of $0.32 \mathrm{nmol} \mathrm{I}^{-1}$ ) in half of the samples taken. Before or at the time of conception there were no differences in the progesterone concentrations between animals carrying fertilized eggs $\left(4.1 \pm 1.7 \mathrm{nmol} \mathrm{I}^{-1}\right)$ and females that had aborted $\left(4.5 \pm 2.3 \mathrm{nmol} \mathrm{I}^{-1}\right)$ and serum progesterone was lower in females that did not conceive (controls) (2.5 \pm $0.8 \mathrm{nmol} \mathrm{I}^{-1}$; Figs 1 and 2). In animals that aborted, no increases in serum progesterone concentrations were observed at 2 or 3 weeks after exit from hibernation. In pregnant animals, serum progesterone concentration increased significantly until 4 weeks after exit from hibernation, the third week of pregnancy $(12.2 \pm$ $0.5 \mathrm{nmol} \mathrm{I}^{-1}$ ) and remained constant thereafter or even showed a tendency to decrease (Figs 1 and 2). After parturition, serum progesterone concentrations decreased to $4.9 \pm 1.9 \mathrm{nmol} \mathrm{I}^{-1}$ (range $\left.0.4-10.45 \mathrm{nmol} \mathrm{I}^{-1} ; n=5\right)$.

The stage of pregnancy had no effect on total oestrogen concentration in the pregnant animals. Values ranged between $117.9 \pm 33.1 \mathrm{pmol} \mathrm{I}^{-1}$ in the first week and $72.8 \pm 19.0 \mathrm{pmol} \mathrm{I}^{-1}$ in the final week of pregnancy. There were no differences compared with the combined females that aborted and non-pregnant females, with values ranging from $112.86 \pm 25.9 \mathrm{pmol} \mathrm{I}^{-1}$ in the second week after emergence from hibernation to $39.8 \pm$ $13.8 \mathrm{pmol} \mathrm{I}^{-1}$ in the last week of observation.

Immediately after emerging from hibernation, all successfully mated females showed significantly higher serum relaxin values than non-successful animals $(1.21 \pm 0.1 \quad(n=15)$ versus $0.32 \pm 0.02(n=5) ; P<$ 0.01 ). These higher relaxin concentrations were maintained until the end of pregnancy (Fig. 3). However, there were considerable individual differences in relaxin production among the animals. One marmot gave birth to five pups, in contrast to three animals resorbing some of four developing embryos. The mean as well as the maximum relaxin concentration in the female that gave birth to five pups was considerably higher (mean: $1.85 \pm 0.22$ versus $1.16 \pm 0.12 \mathrm{ng} \mathrm{ml}^{-1}$; maximum: 3.54 versus $2.00 \pm 0.29 \mathrm{ng} \mathrm{ml}^{-1}$ ). A complete resorption of all embryos during the second or third week of pregnancy led to a gradual decline in relaxin as well as 
(a)

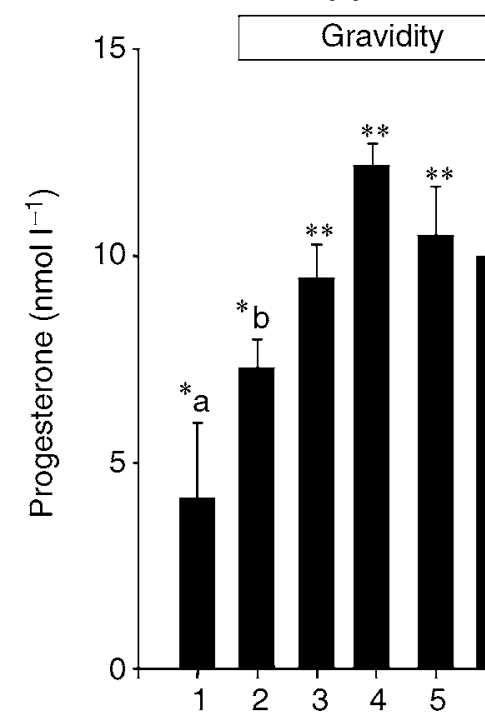

(b)

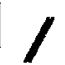

(c)

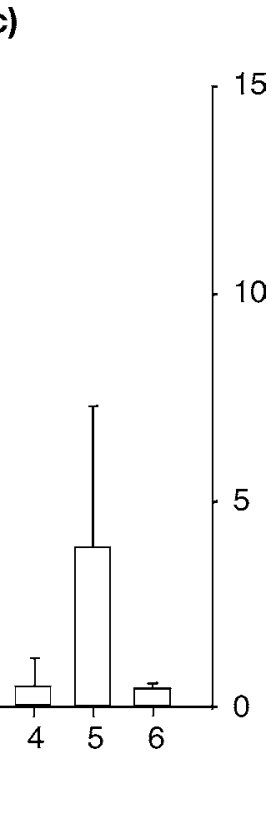

Fig. 1. Serum progesterone concentrations in (a) pregnant Alpine marmots (Marmota marmota) $(n=10)$, (b) marmots that aborted $(n=3)$ and $(c)$ non-pregnant marmots $(n=11)$. *a: significant difference week 1 versus weeks 3-6 after emergence from hibernation of pregnant animals $(P<0.05)$; *b: significant difference week 2 versus weeks 3-5 after emergence from hibernation of pregnant animals $(P<0.05)$; **: significant difference between the pregnant and the other groups combined $(P<0.01)$.

in progesterone to concentrations comparable to those observed in the non-pregnant control group (relaxin: from $1.06-1.47$ to $0.4-0.65 \mathrm{ng} \mathrm{ml}^{-1}$; progesterone: from 8.9-9.1 to $0.4-0.5 \mathrm{nmol} \mathrm{I}^{-1}$ ).

The first copulation in the pregnant female group was observed just one day after the animals awoke from hibernation (Fig. 2). Maximum mating activity occurred on day 37 before parturition, whereby a single female was mated up to 30 times by the dominant as well as the subdominant male (Fig. 2a-c). Copulations occurred with both dominant $(n=2)$ and subdominant females $(n=2)$ and were affected by the number of males. In the pen that contained only one sexually mature male, mating behaviour was monitored for 1 day only (Fig. 2b), whereas in the groups with two males, mating occurred more frequently during the observations (total copulations 31 and 60 in the groups with two males versus 7 in the single male group). Females of the family group with high progesterone concentrations (Fig. $2 \mathrm{~d}$,f) were more sexually active than the corresponding females of the same group. Numbers of copulations in the pregnant animal group ranged from 17 to 54 and in the nonpregnant females from 9 to 14 . In the latter group, the progesterone concentrations were near or below the detection level and were up to $11.2 \mathrm{nmol} \mathrm{I}^{-1}$ in one sample only. The marmots gave birth after a gestation period of 37 days. In one case, a subdominant female gave birth to two living pups. In all groups, the entrances to the nest boxes were sealed by the animals themselves the day before the young were born.

Social interaction within a particular group was influenced by the number of marmots in the group, and was lower in the group of two members (96 \pm 12 interactions per animal during the observation period) than in the two family groups of four members $(170 \pm$ 29 interactions per animal during the observation period). More social interaction tended to be initiated by males rather than females $(192 \pm 28$ versus $118 \pm$ 35 interactions) during the 3 month observation period. Aggressive behaviour within the social group was far less common than behaviour of a clearly positive social nature, and was observed only during the first week after emergence from hibernation, $(2.0 \pm 0.7 \%$ and $72.0 \pm 1.8 \%$ respectively, $n=1386$ interactions). The dominant animals initiated two-thirds of the negative social interactions. The amount of agonistic behaviour towards animals from a neighbouring group was influenced by the number of territorial borders that had to be defended (one territorial border: 493 and 502 individual actions per group; $n=2$; two borders: 1075 individual actions per group; $n=1$ ). Almost $90 \%$ of border-defending behaviour occurred during the first 6 weeks of observation and was undertaken mainly by the dominant animals $(72 \pm 15 \% ; n=4)$. No genderrelated differences were found (female: $47.3 \pm 7.4 \%$; $n=5$; male: $52.6 \pm 7.4 \%, n=5$ ). 
(a)

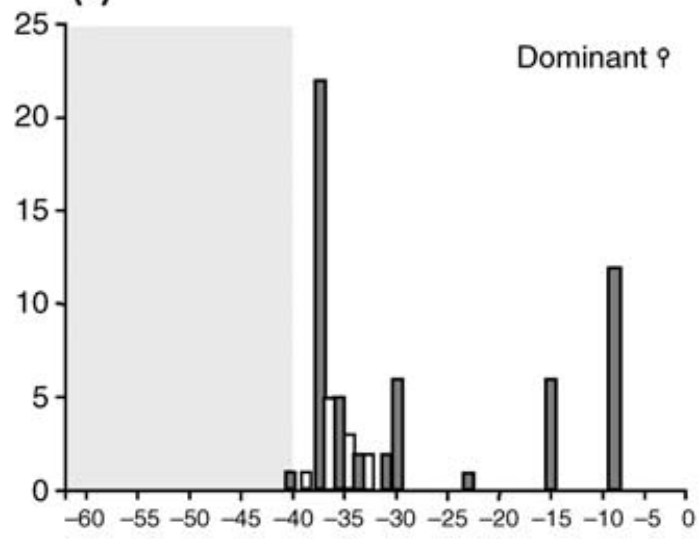

(c)

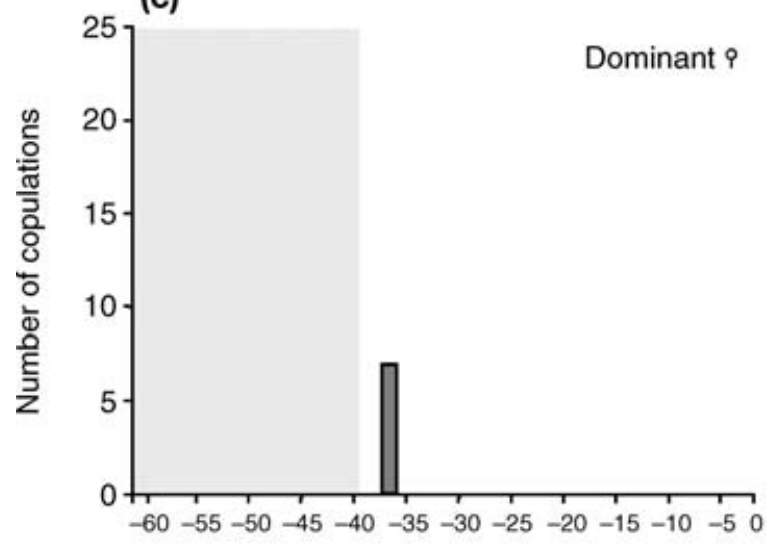

(e)

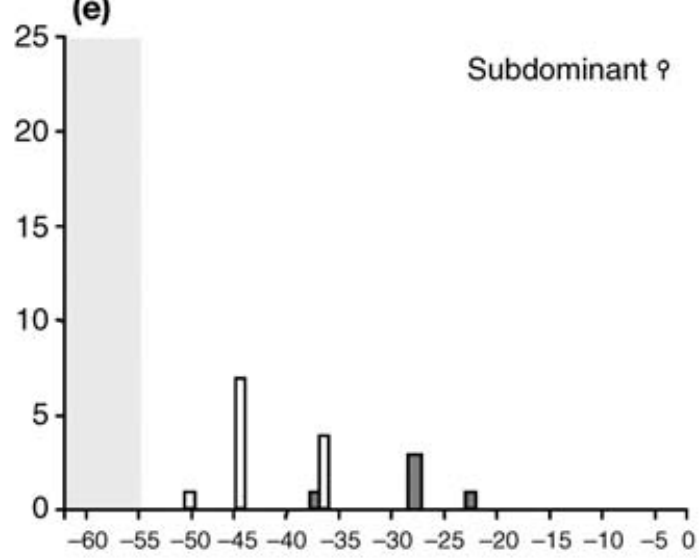

(b)

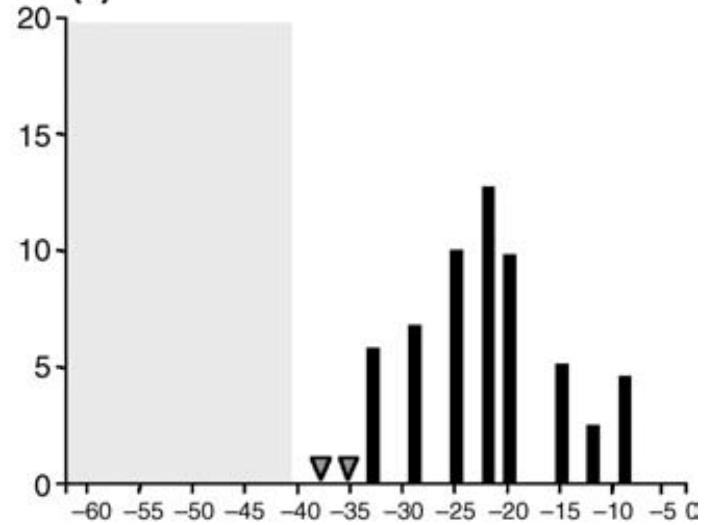

(d)

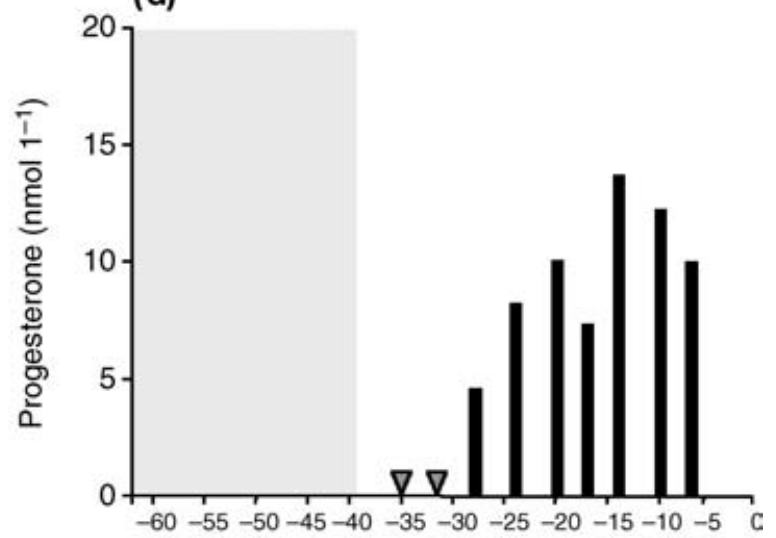

(f)

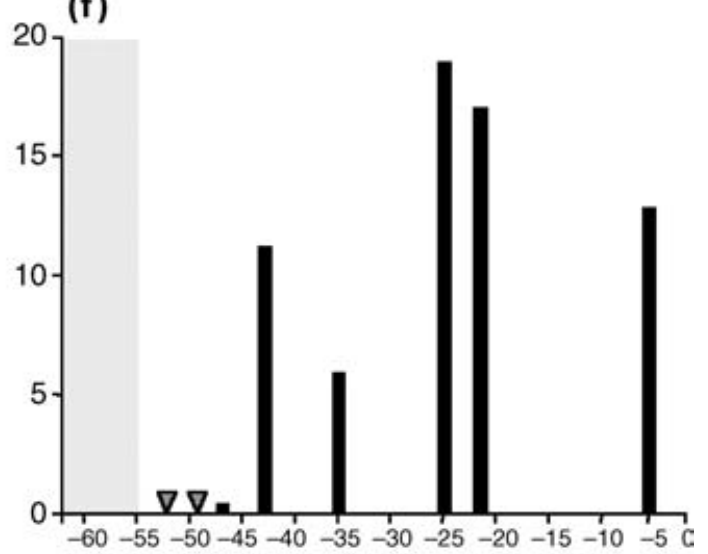

Days before parturition

Fig. 2. Comparison between mating behaviour and progesterone concentrations in dominant $(n=2)$ and subdominant $(n=1)$ pregnant Alpine marmots (Marmota marmota) of three different groups. (a,c,e) Number of copulations between the pregnant female of a group and the dominant (grey barrow) or subdominant (white barrow) male; (b, $d$, $f$ ) corresponding serum progesterone concentrations during the course of pregnancy. Grey triangle: progesterone concentration below the detection level; grey shading: time in climate chamber for hibernation.

\section{Discussion}

Reproduction is strictly seasonal in Alpine marmots, and mating occurs directly after the animals emerge from hibernation (Bibikow, 1996). The physical fitness of the female is a decisive factor in successful reproduction (Frisch, 1985; Bronson, 1989; Hackländer and Arnold, 1999), as is confirmed in studies showing that successfully reproducing animals have higher body weights than non-reproducing females. The difference 


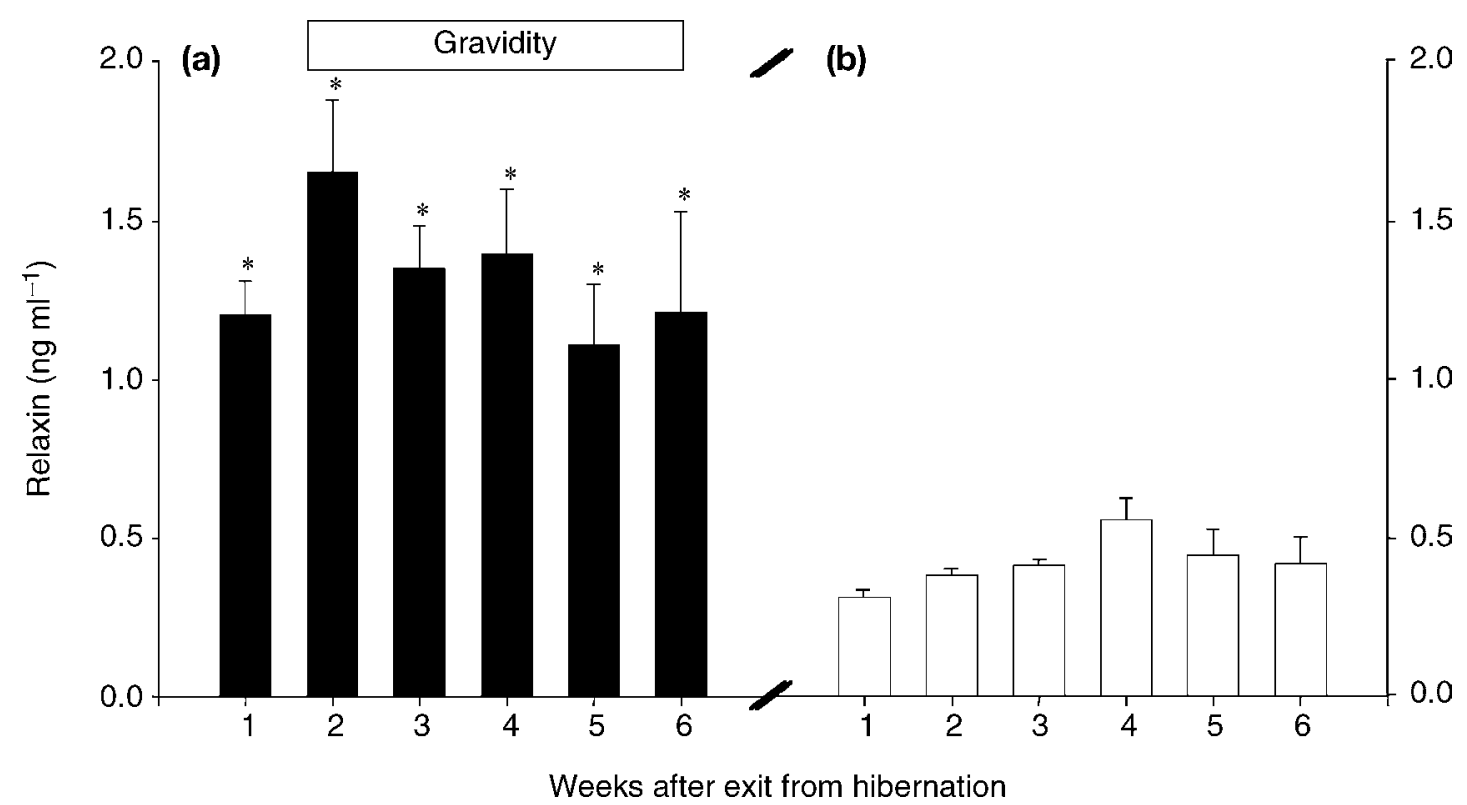

Fig. 3. Relaxin concentration in (a) pregnant $(n=5)$ and (b) non-pregnant $(n=5)$ Alpine marmots (Marmota marmota). Pregnancy was confirmed by ultrasound investigation. *Significant differences between the pregnant and the non-pregnant control females $(P<0.01)$.

in body weight between pregnant and non-pregnant females in the groups in the present study was maintained until the pregnant animals gave birth. In the pregnant females, the weight gain might be influenced by the greater mass of the pregnant uterus and the fetus. In the present study, the maximum number of copulations was observed at 37 days before birth, indicating a gestation period of 37 days. However, as in woodchucks, mating activity and attempts at copulation can also be observed in Alpine marmots during the entire period of gestation (Concannon et al., 1997). In the wild, copulations between subdominant animals are observed, but only the offspring of dominant females were detected (Arnold, 1990; Hackländer and Arnold, 1999). In captivity, a stable social structure with little antagonistic behaviour can contribute to the reproductive success of subdominant females. Antagonistic behaviour among neighbours does not affect the reproductive success of the females. Positive ultrasound findings and the temporary increases in progesterone found during the first half of the mating season in subdominant females confirm that they had successfully mated but had lost the fetus during an early stage of pregnancy. Antagonistic behaviour within a social group can be the main cause of unsuccessful reproduction among subdominant females (Busch and Zerobin, 1995) and can lead to embryonic death and resorption during early pregnancy.

Oestrogen concentrations in Alpine marmots during the mating season and the subsequent period of gestation were considerably lower than those found in Spermophilus beecheyi (Holekamp and Talamantes,
1991) and Spermophilus citellus (Millesi et al., 2000). Unlike other members of the Sciuridae (Spermophilus beecheyi; Holekamp and Talamantes, 1991), the oestrogen concentrations of Alpine marmots do not increase during gestation. This oestrogen profile is similar to that of domestic dogs, in which it is assumed that the corpora lutea are responsible for the low oestrogen concentration (Hoffmann et al., 1994). In marmots, the increase in progesterone during gestation is similar to that of numerous other species (Wagner et al., 1974), including woodchucks (Concannon et al., 1983), grey squirrels (Sciurus coroloinenses; Tait et al., 1981) and yellow-bellied marmots (Marmota flaviventris; Armitage and Wynne-Edwards, 2002). Although the progesterone concentrations are lower in Alpine marmots than they are in woodchucks and yellow-bellied marmots, the overall profile is similar, indicating an ovarian source of progesterone. Authors of studies in grey squirrels (Tait et al., 1981) and musk shrews (Suncus murinus; Hasler and Nalbandov, 1970) speculate that progesterone is of placental origin. As in woodchucks (Concannon et al., 1984), serum progesterone concentration is reduced in Alpine marmots near the time of parturition, indicating a peripartum decline in this hormone. In Alpine marmots, progesterone concentrations decreased within a few hours after birth. In two animals, the concentration decreased to $0.4 \mathrm{nmol} \mathrm{I}^{-1}$, and in three other animals values between 6.6 and $10.5 \mathrm{nmol} \mathrm{I}^{-1}$ were measured. This decline seems to be either extremely transient or inconsistent, as progesterone concentrations were higher in some females for several hours after parturition. 
A prerequisite for parturition is neutralization of the muscle-relaxing effect of progesterone on the myometrium and can be influenced by a complete cessation of progesterone production before parturition, or a reduction of progesterone receptors in the myometrium (Klauke and Hoffmann, 1992). The small number of animals involved in the study prevents any attempt to explain the possible cause of these differences.

Relaxin has a role in pregnancy in many species, for example mice, rats and dogs (Sherwood, 1994). The results of the present study indicate that the role of relaxin in implantation in Alpine marmots may be more important than its role in parturition. There is a marked and significant increase in peripheral relaxin concentration in pregnant Alpine marmots compared with non-pregnant animals, indicating that relaxin could be a useful early marker for pregnancy in this species. The increase in peripheral relaxin concentrations in early pregnancy indicates that there is local embryodependent production of the hormone in the uterus. The endometrium and the placenta are major sources of relaxin production in pregnancy in several species (Norman et al., 1993; Stewart et al., 1993; Einspanier et al., 1999). Whether this is also true of Alpine marmots requires further investigation. However, changes in the endometrium are necessary to prepare an appropriate environment for the implanting embryo and to enable a well-coordinated interaction between maternal and fetal tissues. Relaxin is likely to be of major influence here, as it is produced locally in maternal and fetal tissues, is able to modulate extracellular matrix (Hwang et al., 1996) and stimulates expression of vascular endothelial growth factor (Unemori et al., 1999). Therefore, it is plausible that such local decidual or placental relaxin could have a paracrine effect on fetal-maternal interaction, as well as correlating with the number of implanted embryos in Alpine marmots, as is the case in human embryo implantation (Norman et al., 1993).

\section{References}

Armitage KB and Wynne-Edwards KE (2002) Progesterone concentration in wild caught yellow-bellied marmots: Holarctic marmots as a factor of biodiversity. In Proceedings of the 3rd International Conference on Marmots pp 41-47 Eds KB Armitage and V Rumiantsev. ABF Publishing House, Moscow

Arnold W (1990) The evolution of marmot society: why disperse late? Behavioral Ecology and Sociobiology 27 229-237

Arnold W, Heldmaier G, Ortmann S, Pohl SH, Ruf T and Steinlechner S (1991) Ambient temperature in hibernacula and their energetic consequences for Alpine marmots Journal of Thermal Biology 16 223226

Barash DJ (1976) Social behaviour and individual differences in free-living Alpine marmots Animal Behavior 24 27-35

Bibikow DI (1996) Murmeltiere dieser Welt. Ed. DI Bibikow. Spektrum Akademieverlag, Heidelberg

Blumstein DT and Armitage KB (1998) Life history consequences of social complexity: a comparative study of ground dwelling sciurids Behavioral Ecology 9 8-19

Bronson FH (1989) Mammalian Reproductive Biology University of Chicago, Chicago
Busch W and Zerobin K (1995) Fruchtbarkeitskontrolle bei Groß- und Kleintieren G Fischer Verlag Jena, Stuttgart

Concannon P, Baldwin B, Lawless J, Hornbuckler W and Tennant B (1983) Corpus lutea of pregnancy and elevated serum progesterone during pregnancy and postpartum anoestrus in woodchucks Biology of Reproduction 29 1128-1134

Concannon P, Baldwin B and Tennant B (1984) Serum progesterone profiles and corpora lutea of pregnant, postpartum, barren and isolated females in a laboratory colony of woodchucks (Marmota marmota) Biology of Reproduction 30 945-951

Concannon P, Roberts P, Ball B and Schlafer D (1997) Oestrus fertility early development and autologous embryo transfer in laboratory woodchucks Laboratory Animal Science 47 63-74

Einspanier A, Nubbemeyer R, Schlote S, Schumacher M, Ivell R, Fuhrmann K and Marten A (1999) Relaxin in the marmoset monkey secretion pattern in the ovarian cycle and early pregnancy Biology of Reproduction 61 512-520

Frisch RE (1985) Fatness menarche and female fertility Perspectives in Biology and Medicine 28 611-633

Hackländer K and Arnold W (1999) Male-caused failure of female reproduction and its adaptive value in Alpine marmots Behavioral Ecology 10 592-597

Hasler MJ and Nalbandov AV (1970) Pregnancy in maintenance and progesterone concentration in the musk shrew Biology of Reproduction 19 407-413

Heldmaier G, Ortmann S and Körtner G (1993) Energy requirement of hibernating Alpine marmots. In Life in the Cold pp 195-183 Westview Press, Boulder, $\mathrm{CO}$

Hoffmann B (1977) Bestimmung von Steroidhormonen beim weiblichen Rind; Entwicklung von Messverfahren und physiologische Daten Fortschritte der Veterinärmedizin, Beiheft zum Zentralblatt für Veterinärmedizin, Heft 26 Verlag Paul Parey, Berlin, Hamburg

Hoffmann B, Kyrein HJ and Ender MIL (1973) An efficient procedure for determination of progesterone by radioimmunoassay applied to bovine peripheral plasma Hormones Research 4 302-310

Hoffmann B, Hoveler R, Hasan SH and Failing K (1992) Ovarian and pituitary function in dogs after hysterectomy Journal of Reproduction and Fertility $96837-845$

Hoffmann B, Höveler R, Nohr B and Hasan SH (1994) Investigations on hormonal changes around parturition in the dog and the occurrence of pregnancy-specific non-conjugated oestrogens Experimental and Clinical Endocrinology 102 185-189

Holekamp KE and Talamantes F (1991) Seasonal variation in circulating testosterone and oestrogens of wild-caught California ground squirrels Journal of Reproduction and Fertility 93 417-425

Hwang JJ, Lin SW, Teng CH, Ke FC and Lee MT (1996) Relaxin modulates the ovulatory process and increases secretion of different gelatinases from granulosa and theca-interstitial cells in rats Biology of Reproduction $\mathbf{5 5}$ $1276-1283$

Klauke M and Hoffmann B (1992) Progesterone and oestrogen receptor in the myometrium of the cow during the oestrous cycle and pregnancy and in sheep at the time of parturition Animal Reproduction Science $\mathbf{2 9}$ 195-203

Körtner G and Heldmaier G (1995) Body weight cycles and energy balance in the Alpine marmot Physiological Zoology 68 149-163

Krapp F (1978) Marmota marmota-Alpenmurmeltier. In Handbuch der Säugetiere Europas Bd 1 pp 172-181 Eds B Niethammer and F Krapp. Akademische Verlagsgesellschaft, Wiesbaden

Millesi E, Huber S, Pieta K, Walzl M, Arnold W and Dittami JP (2000) Oestrus and estrogen changes in mated and unmated free living European ground squirrels Hormones and Behavior 37 190-197

Norman RJ, McLoughlin JW, Borthwick GM, Yohkaichiya T, Matthews CD, MacLennan AH and de Kretser DM (1993) Inhibin and relaxin concentrations in early singleton multiple and failing pregnancy relationship to gonadotropin and steroid profiles Fertility and Sterility 59 130-137

Ortmann S and Heldmaier G (2000) Regulation of body temperature and energy requirements of hibernating Alpine marmots American Journal of Physiology 278 R698-R704 
Perrin C, Allaine D and Le Berre M (1993a) Socio-spatial organisation and activity distribution of Alpine marmots Ethology 93 21-30

Perrin C, Coulon J and Le Berre M (1993b) Social behaviour of Alpine marmots seasonal group and individual variability Canadian Journal of Zoology 71 1945-1953

Psenner H (1957) Neues vom Murmeltier Marmota marmota Säugetierkundliche Mitteilungen 5 4-10

Sherwood OD (1994) Female reproduction. In The Physiology of Reproduction 2nd Edn p. 861 Eds E Knobil and JD Neill. Raven Press, New York

Stewart DR, Overstreet JW and Celinker AC (1993) The relationship between hCG and relaxin secretion in normal pregnancies versus periimplantation spontaneous abortions Clinical Endocrinology 38379 385

Strecker JR, Lauritzen C and Goessens L (1979) Plasma concentrations of unconjugated and conjugated estrogens and gonadotrophins following application of various estrogen preparations after oophorectomy and in the menopause Maturitas 1 183-190
Tait AJ, Pope GS and Johnson E (1981) Progesterone concentration in peripheral plasma of non-pregnant and pregnant grey squirrels (Sciurus Carolinensis) Endocrinology 89 107-116

Unemori EN, Erikson ME, Rocco SE, Sutherland KM, Parsell DA, Mak J and Grove BH (1999) Relaxin stimulates expression of vascular endothelial growth factor in normal human endometrial cells in vitro and is associated with menometrorrhagia in women Human Reproduction 14 800-806

Wagner WC, Thompson FN, Evans LE and Molkwu EJ (1974) Hormone mechanisms controlling parturition Journal of Animal Science 3839 57

Received 14 February 2003.

First decision 27 March 2003.

Revised manuscript received 12 August 2003.

Accepted 27 August 2003. 